\title{
EVIDENTIALITY IN ROMANCE LANGUAGES. EXPLANATORY POTENTIAL OF A CONCEPT AND ITS APPLICATIONS IN PRAGMATICS
}

\author{
Gerda HAßLER (D) $\boldsymbol{\Delta}$ \\ University of Potsdam (UNI-Potsdam)
}

๑) open access

EDITORS

- Miguel Oliveira, Jr. (UFAL)

- René Almeida (UFS)

REVIEWERS

- Bert Cornillie (KU Leuven)

- Alexandra Aikhenvald (JCU)

- Marize Mattos (UNESP)

DATES

-Received: $11 / 12 / 2020$

-Accepted: 07/28/2021

-Published: 08/23/2021

\section{HOW TO CITE}

HAßLER, Gerda (2021). Evidentiality In Romance Languages. Explanatory Potential of a Concept and Its Applications In Pragmatics. Cadernos de Linguística, v. 2, n. 1, e337.

\section{ABSTRACT}

Defined narrowly, evidentiality pertains to the sources of knowledge or evidence whereby the speaker feels entitled to make a factual claim. But evidentiality may also be conceived more broadly as both providing epistemic justification and reflecting speaker's attitude towards the validity of the communicated information, and hearer's potential acceptability of the information, derived from the degree of reliability of the source and mode of access to the information. Evidentiality and epistemic modality are subcategories of the same superordinate category, namely a category of epistemicity. Since the first seminal works on evidentiality (CHAFE and NICHOLS 1986), studies have for the most part centred on languages where the grammatical marking of the information source is obligatory (for example WILLETT 1988; AIKHENVALD 2004). Recent years have witnessed a growing interest in the study of the domain of evidentiality in European languages, which rely on strategies along the lexico-grammatical continuum. Assuming a broad conception of evidentiality and defining it as a functional category, we study linguistic means that fulfil the function of indicating the source of information for the transmitted content of a certain proposition in Romance languages. 
RESUMO

Definido de forma restrita, a evidencialidade refere-se às fontes de conhecimento ou de prova em que o falante se sente no direito de fazer uma reivindicação factual. Mas a evidencialidade também pode ser concebida de forma mais ampla, tanto como uma justificação epistémica, como um reflexo da atitude do falante relativamente à validade da informação comunicada e da potencial aceitabilidade da informação por parte do ouvinte, derivada do grau de fiabilidade da fonte e do modo de acesso à informação. Evidencialidade e modalidade epistémica são subcategorias da mesma categoria superordenada, nomeadamente uma de epistemicidade. Desde os primeiros trabalhos seminais sobre evidencialidade (CHAFE; NICHOLS, 1986), os estudos têmse centrado, na sua maioria, em línguas em que a marcação gramatical da fonte de informação é obrigatória (por exemplo WILLETT, 1988; AlKHENVALD, 2004). Nos últimos anos, tem-se assistido a um interesse crescente no estudo do domínio da evidencialidade nas línguas europeias, que se baseiam em estratégias ao longo do continuum léxicogramatical. Assumindo uma conceção ampla da evidência e definindo-a como uma categoria funcional, estudamos meios linguísticos que cumprem a função de indicar a fonte de informação para o conteúdo transmitido de uma determinada proposição, em línguas românicas.

\section{KEYWORDS}

Evidentiality; Functional-Semantic Category; Evidential Markers;

Epistemic Adverbs.

\section{PALAVRAS-CHAVE}

Evidencialidade; Categoria Funcional-Semântica;

Marcadores Evidenciais; Advérbios Epistémicos. 


\section{INTRODUCTION}

In its strict sense evidentiality concerns "the grammatical means of expressing information source, known as evidentials" (AIKHENVALD, 2004, p. XI). In this article, evidentiality and the relationship between evidentiality and the expression of speaker's stance in Romance languages will be examined. As has been said by Alexandra Aikhenvald (2004, p. 1), "in about a quarter of the world's languages, every statement must specify the type of source on which it is based -for example whether the speaker saw it, or heard it, or inferred it from indirect evidence, or learnt it from someone else". Of course, this is not the case in Romance languages, in English or in German. Nevertheless, we can express the information source in all these languages, even if we do not need to express it. We can use for this purpose explicit designations of the source or refunctionalise linguistic means with related meaning. It is precisely the same problem which was observed by Roman Jakobson:

\footnotetext{
If some grammatical category is absent in a given language, its meaning may be translated into this language by lexical means. [...] As Boas neatly observed, the grammatical pattern of a language (as opposed to its lexical stock) determines those aspects of each experience that must be expressed in the given language. [...] Languages differ essentially in what they must convey and not in what they may convey. (JAKOBSON 1959, p. 236)
}

Morphemes and morpheme-like constructions that do not have a referential meaning (any more) but have procedural meaning are regarded as grammatical means of expression. While referential meaning makes it possible to establish a reference to objects and concepts, certain routines of verbalisation and decoding are carried out with procedural meaning. In the case of evidentiality, this means establishing a reference to how the speaker has access to the information.

The extension of the category of evidentiality to lexical means and its application to pragmatic studies has led to a certain blurring of its content. As already stated by Izquierdo Alegría, González Ruiz y Loureda Lamas $(2016,13)$ some of the most basic issues surrounding evidentiality have, since their origins, generated wide-ranging disagreements that have often hindered dialogue between specialists.

Especially in Spanish linguistics, evidentiality has become a very popular subject of investigation (cf. ESTRADA 2013, ALBELDA MARCO 2015; IZQUIERDO ALEGRÍA; GONZÁLEZ RUIZ; LOUREDA LAMAS 2016), and we can find, for example, publications on the following topics

- Convergences in the Andean area: testimoniality and evidence marking in Andean Spanish and Quechua (DANKEL; SOTO RODRÍGUEZ, 2012)

- Evidentialty in Spanish: theory and description (GONZÁLEZ RUIZ; IZQUIERDO ALEGRÍA; LOUREDA LAMAS, 2016) 
- Adverbs as evidentials: an English-Spanish contrastive analysis of twelve adverbs in spoken and newspaper discourse (CARRETERO; MARÍN-ARRESE; LAVID-LÓPEZ, 2017)

These publication titles indicate that it is not systematic facts of the evidential markers of a language that are considered, but the use of linguistic means to fulfil the function of marking the way of accessing the source of knowledge. In the normal, everyday use of the language, we do not have to indicate in the Romance languages where we got our knowledge from, but we can certainly do so. This article will deal with the linguistic means we have at our disposal to indicate the access to the origin of our knowledge. First languages that must always and obligatorily use such means will be presented, then the expression of evidential knowledge in Romance languages will be explained, and it will be discussed what the need to express the origin of the speaker's knowledge can do in languages where the use of evidential means of expression is not obligatory.

On the one hand, the development of the category of evidentiality and the overlap between the two categories of evidentiality and modality are shown, and on the other hand the similarities and differences of their expression in languages that do not have a specialized means of expressing evidentiality are discussed. Finally, it is shown that an awareness of the existence of evidential markers in some languages is already detectable in early descriptions and grammars. Evidentiality is probably the only category that has been successfully transferred from indigenous language descriptions to European languages. In this context it will be shown that evidentiality has an explanatory potential for some linguistic means even in languages which do not have grammaticalized evidentials.

\section{LANGUAGES WITH SPECIALISED EVIDENTIALS}

Let us first consider the expression of the origin of the speaker's knowledge in languages where there are specialised means for this purpose. It is difficult for us to imagine that a statement such as My son has just come back. He played football. should not be possible. When the speaker says this, he does not have to say from where he has his knowledge of the fact that he played football. However, in the Tuyuca language, this statement would not be possible in this way. It must be added from which source the speaker has his knowledge. Tuyuca is an Eastern Tucana language spoken by an indigenous ethnic group of some 5001000 people who inhabit the watershed of three rivers in the Colombian department of Vaupés and the Brazilian state of Amazonas. The Tuyuca language distinguishes (1a) the direct personal and visual experience of the speaker, b) the perception through hearing, (1c) 
making deductions from evidence, (1d) learning from the report of another person and (1e) drawing a conclusion based on logic (cf. BARNES, 1984):

(1) a. díiga apé-wi soccer play-3.PERS.PRET.VISUAL 'He played soccer [l saw it]'

b. díiga apé-ti soccer plaY-3.PERS.PRET.NOT VISUAL 'He played soccer [I heard it but didn't see it]'

c. díga apé-yi soccer play-3.PERS.PRET.INFERENCE 'I have evidence that he played soccer, but I didn't see it.'

d. díiga apé-yigi soccer play-3.PERS.PRET.REPORT 'I was told that he played soccer.'

e. díiga apé-hĩyi soccer play-3.PERS.PRET.CONCLUSION 'It can be logically assumed that he played soccer.'

The highlighted elements are so-called evidentials; they function as a kind of suffix that can be appended to all verbs and which express different origins of knowledge. In contrast, the paraphrases for expressing the source of knowledge in English - as these examples already show - are much more complicated, we need a whole sentence to express what is possible in Tuyuca with one or two syllables. The simple assertion that someone played soccer is not possible in Tuyuca without providing the source of this knowledge. It is important to understand that the access to the source of knowledge can, of course, be expressed in all languages, but that it must be expressed in some languages, and that it must be expressed with grammatical means specialized for this purpose.

But even where marking evidentiality is obligatory, not all languages distinguish all the types of knowledge sources we can find in Tuyuca. There are only a few languages that have obligatory expressions for so-called direct evidentiality. Today, 71 such languages are considered to exist. Direct evidentiality is present when the speaker has perceived the communicated event himself by optical perception, as in the following example (for the following examples (2)-(7) see DE HAAN https://wals.info/example?parameter=77A):

(2) Fasu (Papua New Guinea)

a-pe-re

VIS-come-VIS

'I see it coming.'

There are also specific evidential expressions for acoustic perception in some languages: 


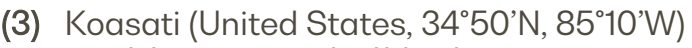

nipó-k aksóhka-ha

meat-SUBJ char-AUD

'It sounds like the meat is charring.'

In most cases, however, there is only one marker for direct evidentiality, which covers all perception through sensory experiences. Although this marker is mostly used for visual experiences, other sensory perceptions are also possible:

(4) Kewa (Papua New Guinea)

tira-a-ha

cook-3.SG.NEAR.PST-DIR.EVD

'He cooked it [l saw/heard/smelled it]'

Many more languages, on the other hand, have means of marking indirect evidentiality, i.e. they have specific markers for conclusions and for hearsay:

(5) Khalkha (Mongolia)

ter irsen biz

he come INFER

'He must have come'

(6) Lezgian (Azerbaijan)

Qe sobranie že-da-lda.

today meeting be-FUT-QUOT

'They say that there will be a meeting today.'

Also, in indirect evidentiality, the two sources of knowledge, one's own conclusions and the experience of hearsay, are often expressed by one and the same linguistic means. This is the case, for example, with the Dutch modal verb moeten 'must':

(7) Dutch

Het moet een goede film zijn.

'It seems to be a good movie.' (I have no direct evidence)

(DE HAAN ttps://wals.info/valuesets/77A-dut)

Thus, different types of evidentiality are assumed, in which first of all the direct evidence as own experience is distinguished from the indirect evidence via communication and conclusions.

On this map the languages with evidentials are listed (DE HAAN, https://wals.info/feature/77A\#2/18.0/149.8) 


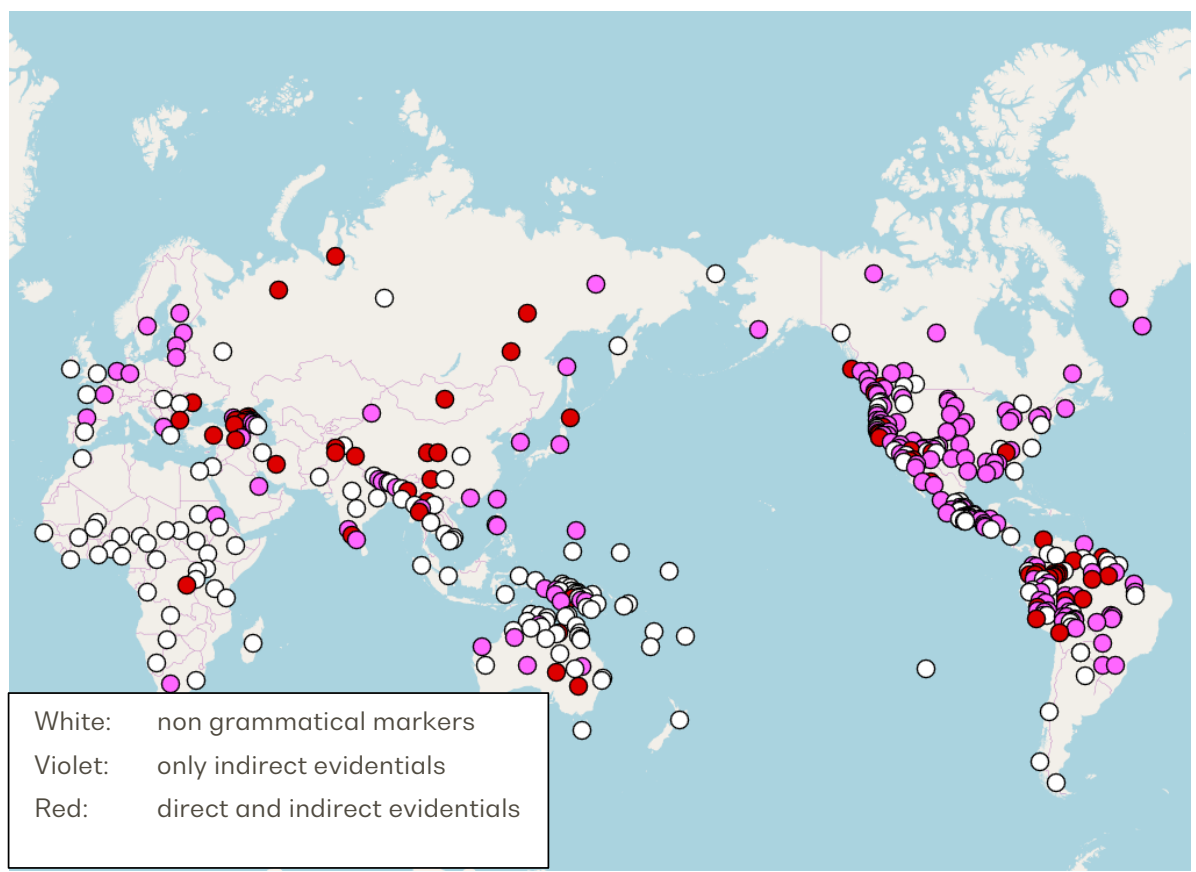

Graph 1. Map of the distribution of evidentials, Ferdinand De Haan, https://wals.info/feature/77A\#2/18.0/149.8

Evidential markings are therefore available in many languages of the world, on all continents, but some geographical peculiarities can be identified. Grammaticalized evidential markers are almost completely missing in Africa. Some European languages have evidentials, but only to express indirect evidentiality. Languages with direct and indirect evidential expressions are concentrated in certain regions, in the western USA, the western Amazon region, the Caucasus, the Himalayas and adjacent areas, but they are by no means limited to these regions. As far as Europe is concerned, indirect evidentials are attributed to the Germanic languages, while typologists tend to deny grammaticalised expressions of evidentiality in the Romance languages. "Grammaticalised" means a form that has largely lost its original lexical meaning and has become the means of expression of a grammatical category, in our case the category of evidentiality.

In the work that led to the creation of the map of evidentiality, it was not considered whether the evidentials must be used in every utterance or whether they can only be added when necessary. In this way, German is also declared to be a language with expressions of indirect evidentiality, although it has only two modal verbs (wollen 'to want' and sollen 'to be to do sth.') that actually can mark evidentiality in certain contexts:

(8)a Maria will ein Buch geschrieben haben. Maria wants a book written have 'Maria said she had written a book.'

(8)b Maria soll ein Buch geschrieben haben. Maria must a book written have 'Maria is said to have written a book.' 
Typologists accept as evidentials linguistic means with the primary characteristic "source of knowledge" without implying any direct reference to the certainty and responsibility of the speaker or to the truthfulness of his statement. Evidentiality and modality are thus always strictly separated, which is indeed the case in some languages with actually fully formed evidential systems. With this limitation, however, the category of evidentiality would not only be inapplicable to European languages, but it would become problematic for anything beyond the identification of elements with evidential core meaning.

Indeed, even in languages with genuine evidentials, evidentiality has points of contact with modality, in so far as its expression also characterizes the caution with which a speaker handles information. One proof that evidential markings take on the pragmatic function of marking the speaker's uncertainty even in languages with pure evidentials is the use of the suffixes -mi/-shi/-chi in the Huallaga dialect of Quechua, which allows the speaker to take or reject responsibility for the content of what is said. With -mi the speaker takes responsibility, with -shi they refer it to someone else, with -chi they indicate that it is a content for which no responsibility can be taken. According to WEBER (1989, 421), with (9) the speaker expresses his certainty, with (10) they refer to a foreign communication and with (11) to a possibility:

(9) Wañu-nqa-paq-mi. ' [l claim] he will die.

(10) Wañu-nqa-paq-shi.' [l am told] he is going to die.'

(11) Wañu-nqa-paq-chi.' [Maybe] he will die.'

The evidential marker of reported speech -shi goes far beyond the expression of second-hand information. It is also used in the so-called narrated past, for which one does not want to take responsibility. A mixture of morphologically conceived evidentials with pragmatic circumstances seems apparent as soon as one goes beyond typological issues to look at the use of these elements. To examine evidentiality in discourse, it is necessary to take the speaker's stance into account, even in languages with pure evidentials. Even more important is the interaction of these two categories in the pragmatic study of evidential discourse meanings in languages without genuine evidentials.

\section{EVIDENTIALITY AS A FUNCTIONAL CATEGORY}

A concept of linguistic universals that focuses on functions and allows that not all languages have grammatical means for the realization of the corresponding function seems promising for the description of the category of evidentiality. It may be assumed that even in the use 
of languages that do not have specialized means in this area, there are situations in which the external source of speaker knowledge or the expression of uncertainty due to inference must be marked obligatorily and in which this marking is also recognized as such.

Operating with typological categories in differently defined contexts has been practised for some time. An example for the description of the category of evidentiality is the typological category of aspectuality, which is also used in the description of languages with verbs that do not have any grammaticalised means for expressing the quality of bounding or "course of action". In accordance with BONDARKO (1984), we assume that the aspect correlation "perfective" vs. "imperfective", as is found in the Slavic languages and in Greek, forms the core of a functional-semantic category characterised as aspectuality.

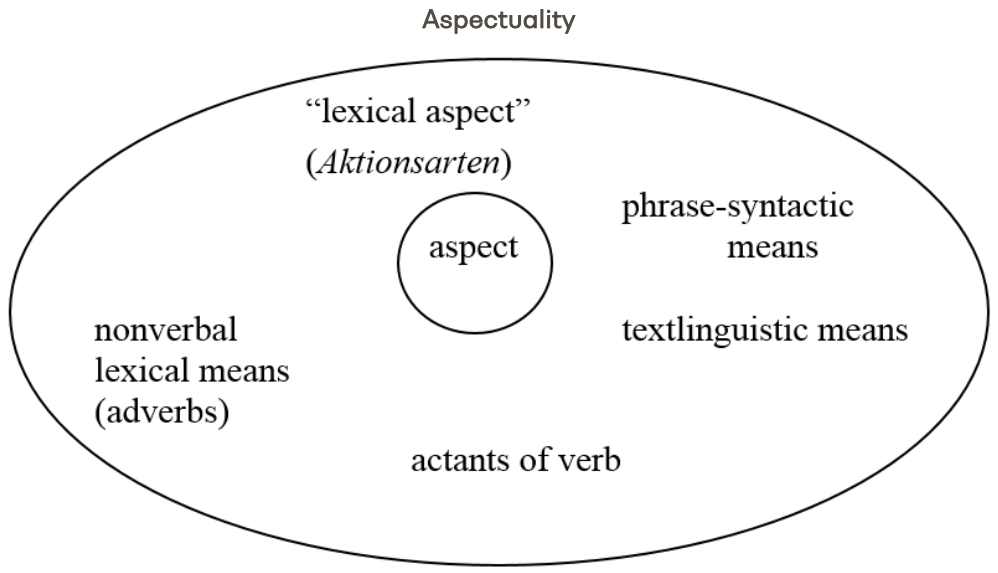

Graph 2. The functional-semantic category of aspectuality.

On the periphery, several additional linguistic means, such as types of actions ("Aktionsarten") and adverbs belong to aspectuality. In this sense Bondarko considers it justified to assume a functional-semantic category of aspectuality even for languages lacking the grammatical core of aspectuality, the verbal aspect (BONDARKO 1984). The basis for this transfer of a typological category to semantic and pragmatic circumstances is the assumption that there is a universal need for expression of the function taken over by the relevant category, which in languages lacking the grammatical core of the category can be assumed by other linguistic means, which thus have a greater diversity and can be polyfunctional. We could generalise this view in order to apply it to evidentiality: 


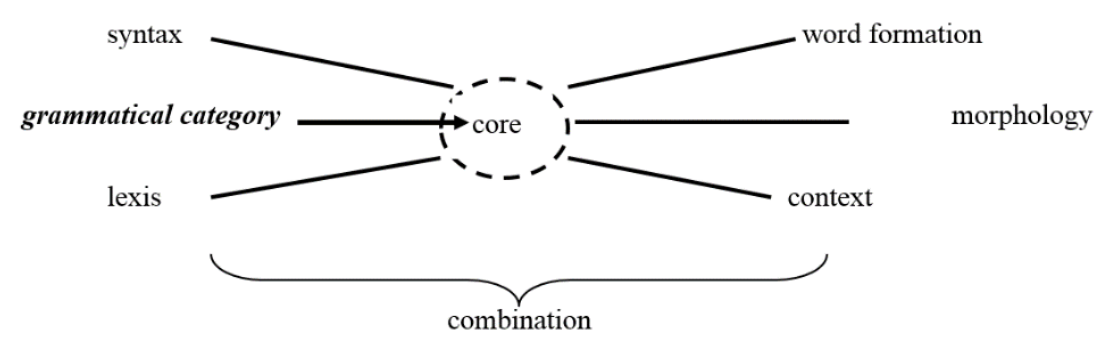

Graph 3. General structure of a functional-semantic category.

For the Romance languages, English, and German no linguistic means can be found which could be assigned to a core of evidentiality. Since there are not any forms of expression that would be grammaticalised with this function, the core would remain empty. However, other forms of expression could be assigned, which in certain contexts could take over evidential functions. Here we mention a few, initially unordered examples. In the sequence of the enumeration we follow the usual designations of the kinds of evidentiality in typological works (cf. BARNES, 1984)

- visual access can be marked by adverbs, for example: span. visiblemente 'visibly', span. aparentemente 'apparently' and span. evidentemente 'evidently, obviously' (and their equivalents in other Romance languages)

- inference can be marked for instance by modal verbs: fr. // doit l'avoir fait par pitié. 'He must have done it out of pity.'

- inference can also be marked by future which also expresses epistemic modality: italian La segretaria sarà malata. 'The secretary will be ill. (because she is not here)'

- information by others is often marked by the journalistic conditional, like in the Spanish sentence El general Díaz Alegría se habría trasladado a París. ('General Díaz Alegría would have moved to Paris').

- For the expression of information by others or hearsay evidential constructions can be used, like si dice in Italian or diz que in Portuguese: it. si dice che la quotazione in Italia sia propedeutica a nuove acquisizioni. 'It is said that having quotas in Italy paves the way for new achievements.', sp. Dizque llegaron tarde. 'It is said that they arrived late.'

- hearsay is marked by German modal verbs wollen and sollen: Maria soll ein Buch geschrieben haben. 'I heard that Maria wrote a book.' Maria will ein Buch geschrieben haben. 'Maria claims to have written a book.' 
In this sense we consider evidentiality to be a structural dimension of grammar, the values of which are expressed by types of constructions that code the access to the source of information which a speaker imparts. Usually we differentiate between direct and indirect evidentiality (cf. WILLETT, 1988, 57):

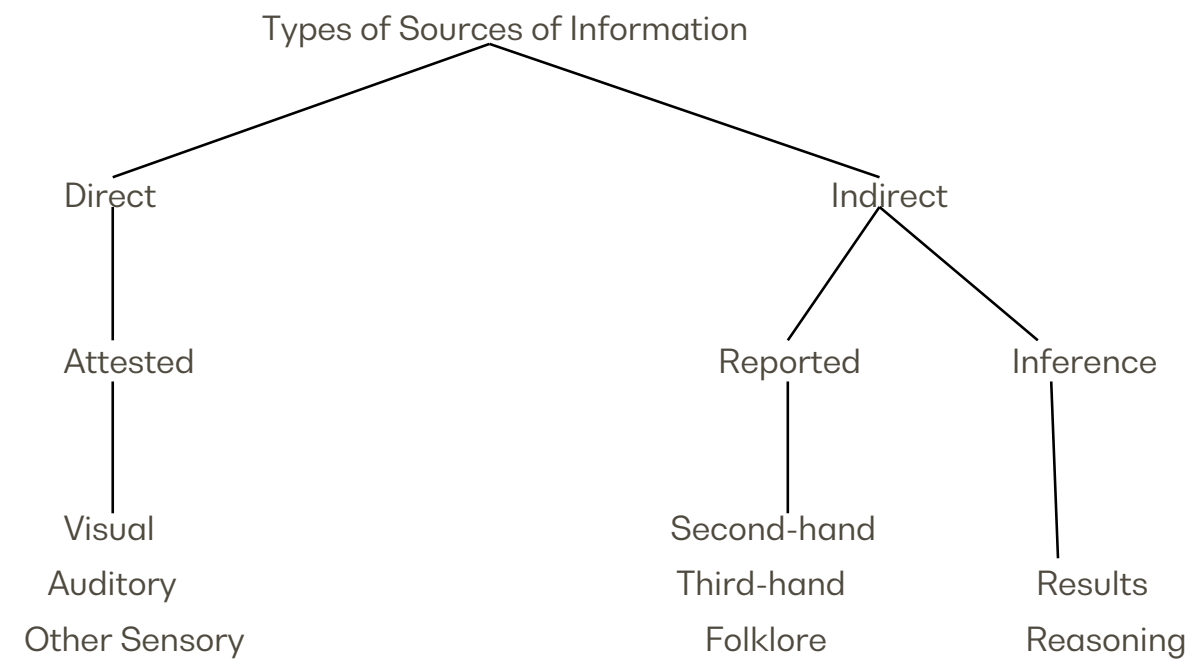

Graph 4. Types of modes of access to information.

Direct evidential expressions are used by the speaker when they themselves (visually, auditorily or through other senses) have perceived the occurrence about which they report in the evidentially marked utterance (cf. DE HAAN, 2001, 203). In this case the described event has taken place within the deictic sphere of the speaker (cf. DE HAAN, 2005, 2). Indirect evidential expressions come into use when the speaker did not perceive the occurrence themselves, but was informed of it by others. If the speaker therefore uses indirect evidential markings, the event expressed by them took place outside of their deictic sphere (cf. DE HAAN 2005: 2). If the represented content is a conclusion, and if this is characterised as such, we refer to this as using inferential markers.

In analogy to the category of aspectuality, we can represent the functional category of evidentiality like this: 


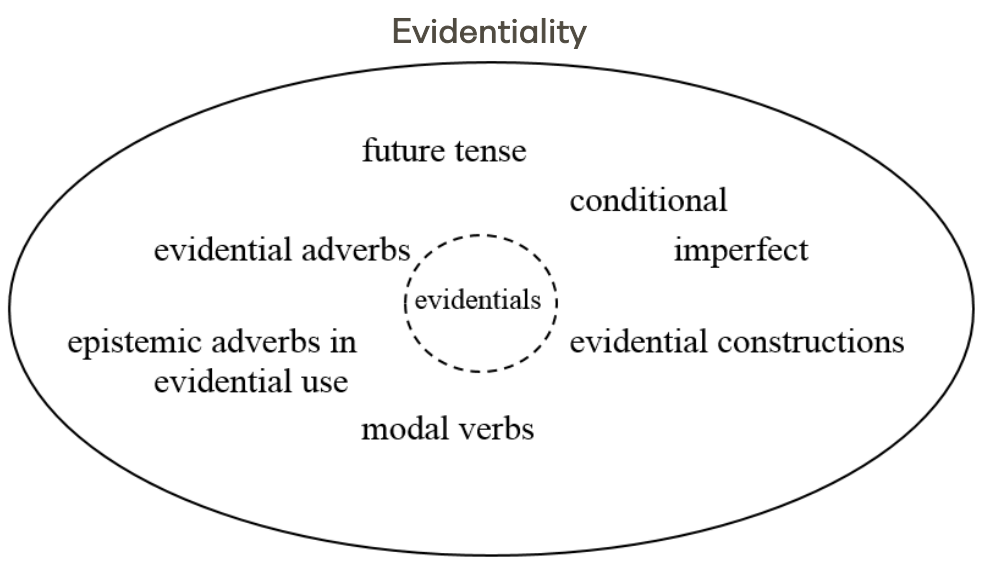

Graph 5. The functional-semantic category of evidentiality.

The core of the category, the evidentials, would be empty in many languages, and the linguistic means in the periphery will not be called evidentials, but evidential markers. They may also perform other functions, in particular in the identification of temporality, aspectuality and modality.

The need to mark the origin of the knowledge communicated is essential for certain areas of communication, even in languages without the core category of grammaticalised evidentials. In these cases, it would not be a grammatical constraint as in the examples we have seen from Tuyuca, but a pragmatic constraint imposed by cognitive and communicative needs.

I would like to briefly illustrate what can arise when evidential markings are ignored, using a discourse in connection with the recent crisis surrounding the coronavirus in Germany. In April 2020, a renowned virologist, Christian Drosten, posted a study on his server - not yet published in a journal - in which he suspected that children could carry as many viruses in their throat as adults and thus be just as infectious. He had just formulated this as an assumption that he had derived from an imperfect set of data. Of course, this conjecture was highly explosive, because he was then held responsible for the closure of the schools. At the end of April, Drosten received a great deal of criticism, not only from scientists, but even death threats from the population. One reason for this was certainly the way some newspapers reported on his study. All these headlines are from April 30, 2020

(12) Corona-Studie: Kinder sind genauso ansteckend wie Erwachsene ('Corona study: Children are just as infectious as adults'. https://www.bild.de)

(13) Kinder haben so viele Viren im Rachen wie Erwachsene ('Children have as many viruses in their throat as adults'. https://kurier.at/wissen/gesundheit/studie-kinder-haben-soviele-viren-im-rachen-wie-erwachsene/400828259) 
(14) Kinder vermutlich genauso ansteckend wie Erwachsene ('Children presumably as contagious as adults'. https://www.forschung-und-lehre.de/kinder-vermutlichgenauso-ansteckend-wie-erwachsene-2742/)

In the first two headlines (12 and 13), there is neither a limitation of the validity of the statement nor an indication of the origin of the content communicated. Only the journal of the German Association of Universities characterizes the content as a conjecture, using the adverb vermutlich 'presumably'. In the first two headings, the principle of cooperation is manifestly infringed, insofar as something is claimed to be true for which there is no evidence. This is made worse by omitting the reference to the basis of the presumption and the fact that it is a conclusion, which is naturally contained in the study.

\section{EVIDENTIAL MARKERS IN ROMANCE LANGUAGES}

If we now turn to evidentiality in the Romance languages, of course we do not have to reckon with grammaticalized evidentials, that means with constructions which always appear with the procedural meaning of designating the access to the source of the information. As a grammatical category, evidentiality encodes information source as its primary meaning (cf. for example BOYE 2018, 261-263; SENTí 2020, 29). Although such evidentials are lacking in Romance languages, there are some evidential strategies which make use of the lexicalgrammatical continuum (CORNILLIE 2007; SQUARTINI 2001; 2008; PIETRANDREA 2007; SENTI 2020). With the development of construction grammatical approaches, it became possible to describe the language system as a continuum in which grammatical and lexical units differ only in terms of their complexity and degree of abstraction. This proves particularly advantageous in the consideration of non-compositional form-meaning pairs of different degrees of complexity and abstraction.

As Squartini $(2018,274)$ has pointed out, current studies on evidentiality are "still divided between a 'grammar-only' conception and the extensive idea of 'all-purpose evidentiality". With the notion of 'evidential strategy' the possibility of an extension of the concept of 'evidentality' to "secondary, possibly pragmatic, extensions that participate" (SQUARTINI 2018, 274) in marking the evidential character of an utterance was opened. Aikhenvald admits the relevance of evidential adverbs or verbs like sayor see, but as they gradually grammaticalize, they become part of (semi)closed classes of particles and modals which can be considered as "evidentials in the making" (AIKHENVALD 2007, 220; cf. SQUARTINI 2018, 275). In discourse grammars a rigid boundary between grammar and 
lexicon is eliminated and the interplay of evidential lexical items is brought into focus (SQUARTINI 2018, 275).

To illustrate the problem of "extragrammatical expression" (SQUARTINI 2018, 273), a French example of the evidential hierarchy established for the Tuyuca language will be taken. Against the background of a common statement about the factual situation $p$, linguistic means can also be contrasted in French that indicate the source from which the information was obtained (DENDALE; TASMOWSKI, 1994, 5):

(15) Monsieur Leclerc est à l'université.

'Mr. Leclerc is at university'

\section{p}

(16) Monsieur Leclerc doit être à l'université, car j'ai vu sa voiture au parking.

conclusion $\mathrm{q} \rightarrow \mathrm{p}$

'Mr. Leclerc must be at the university, because I saw his car in the parking lot.'

(17) Monsieur Leclerc serait à l'université. 'Mr Leclerc would be at the university.'

p out of foreign utterance $q$

(18) Monsieur Leclerc est à l'université, j'ai vu. p from one's own perception Mr Leclerc is at the university, I saw.

In the statement (15), which is unmarked from the point of view of evidential value, the speaker simply states the facts of the case without mentioning where he got his knowledge from. The verb form in the indicative also corresponds to this, while obviously the conditional in example (17) is evidentially more strongly marked. In (17) the evidential meaning of the conditional is not supported by a modal auxiliary verb, a sentence adverb or any other means. Statement (16) differs from (17) in that the speaker explicitly communicates the source of his knowledge in it: Mr. Leclerc must be at the university because I saw his car. I do not consider such explicit indications of the source of the speaker's knowledge as in (16) to be evidential markers, since they take the form of a separate sentence. Evidential markers, on the other hand, function as additional information within a sentence, like the modal verb in (16), the conditional in (17) or the construction j'ai vu in (18). The addition in (18) iai vu cannot be considered as a sentence with its own predication, since it lacks a complement (je l'ai vu). It only refers to the visual origin of the content communicated in the main clause.

Since it is not possible to deal with all linguistic devices that can mark evidentiality in Romance languages in this framework, one lexical and one grammatical device will be selected. First evidential and epistemic adverbials which have received much attention in research in recent years are treated, and then the refunctionalization of the imperfect as an evidentiality marker will be considered, before turning to some emerging evidential markers. If no other source is indicated, the examples used come from the following corpora: for Spanish the Corpus de Referencia del Español Actual (CREA, 
https://www.rae.es/banco-de-datos/crea) was used, and for French the corpus Frantext (https:// //www.frantext.fr).

\subsection{EVIDENTIAL AND EPISTEMIC ADVERBS}

Most of the studies on evidential markers concern adverbs which fulfil the original function of designating the source of the speaker's knowledge. This is contingent with the marking of the speaker's stance and epistemic modality. If we look at the situation in Romance languages, drawing a boundary between speaker's stance, epistemic modality and evidentiality presents problems that are difficult to solve (CORNILLIE, 2007; 2018; HENNEMANN 2013).

This can be seen in the Spanish adverbs visiblemente 'visibly', aparentemente 'apparently' and evidentemente 'evidently, obviously', which in their direct meaning denote visual access to the content of the proposition. However, while this access for visiblemente is explicit (19), aparentemente and evidentemente can also denote conclusions which are not based on visual perception, but on hearsay (20) or inference (21) (cf. HAßLER, 2004).

(19) La suma de estos quebrantos - que se hizo evidente cuando el gobierno debió renegociar su gigantesca deuda externa - ya obligó al Presidente Figueiredo a someterse a una delicada operación de by-pass y lo ha afectado visiblemente en lo físico. (Hoy, 25/04-01/05/1984)

'The sum of these losses, which became evident when the government had to renegotiate its gigantic foreign debt, had already compelled President Figueiredo to undergo a serious by-pass operation and had visibly affected him physically.' (CREA, Hoy, 25/04-01/05/1984)

(20)Esta confianza estaba evidentemente fundada en la disposición general de todos los españoles, que guiados por el instinto de la felicidad, que el autor de la naturaleza puso en el corazón de los hombres, sabían que no había otro camino para que se mejorase la suerte de la España, que el de cambiar las instituciones, ni otro medio de conseguirlo que por un alzamiento militar. (CREA, El Imparcial, 1 de febrero de 1822)

'This trust was evidently based on the general disposition of all Spaniards who guided by the instinct of happiness which the creator of nature has placed in the human heart - knew that there was no other way for the fate of Spain to turn positively than to change the institutions, and there was no other means to achieve that than by a military uprising.'

(21) $Y$, de igual manera que en el Estado jurídico se destacan lazos legislativos que descubren y ordenan las relaciones en todo el ámbito nacional, porque a todos 
protegen y a todos obligan las relaciones aparentemente invisibles de la colectividad, de la misma manera en el ámbito económico nacional hay que descubrir también las interrelaciones económicas entre los distintos sectores, [...]. (CREA, Contabilidad Nacional, ABC, 11 de julio de 1958)

'And in the same way that in the lawful state legislative ties dominate which uncover and organise the relationships on the entire national level because they protect everyone and oblige everyone to uphold the apparently invisible relationships of the group, in the same way on the national economic level one must also uncover the economic interrelationships between the different sectors [...].'

As example (21) shows, aparentemente is readily combinable with elements which negate visibility (aparentemente invisibles).

The data from the French corpus Frantext also confirm this usage of evidential adverbs, whereby apparemment in particular is also used increasingly within a narrow scope, i.e. with evidentialising function only with reference to a word or a part of the sentence. In the following sentence, apparemment refers to the property of superiority to be decisive and thus marks this quality as conclusions or coming from hearsay:

(22) [...] je n'ai jamais bien compris la nature de cette supériorité apparemment decisive (Frantext, ${ }^{1}$ R210 - Genette, Gérard, Bardadrac, 2006, 308)

[...] I never understood the nature of this apparently decisive superiority (Frantext, R210

- Genette, Gérard, Bardadrac, 2006, 308)

None of the mentioned examples aim to state visible facts, but rather to convey conclusions. The evidential meaning of the adverb has clearly shifted from characterising visually observable phenomena to conveying one's own conclusions. Inferential evidentiality and epistemic modality are expressed by these adverbs in equal measure. Besides this, in using the adverbs, the speaker subjectifies their statement, they convey their stance.

It seems possible in these cases to speak of a lexical meaning that is ultimately based on the fact that always whenever the speaker seems motivated to explicate evidence, a reduction of the degree of evidentiality takes place as well. It is not that the content of the utterance is apparent, not that it is visible, but rather the non-presence, the not-mentioning of the information source which is decisive for the use of the adverbs. 
At the same time, these examples show that the marking of evidentiality cannot be separated from the subjectification of the utterance, its relativisation to the epistemic centre of the speaker and thus the expression of speaker's stance. It seems once again confirmed that the speaker's perspective is a superordinate category, which includes several overlapping subcategories (HENNEMANN, 2013: 419, see also BOYE, 2012):

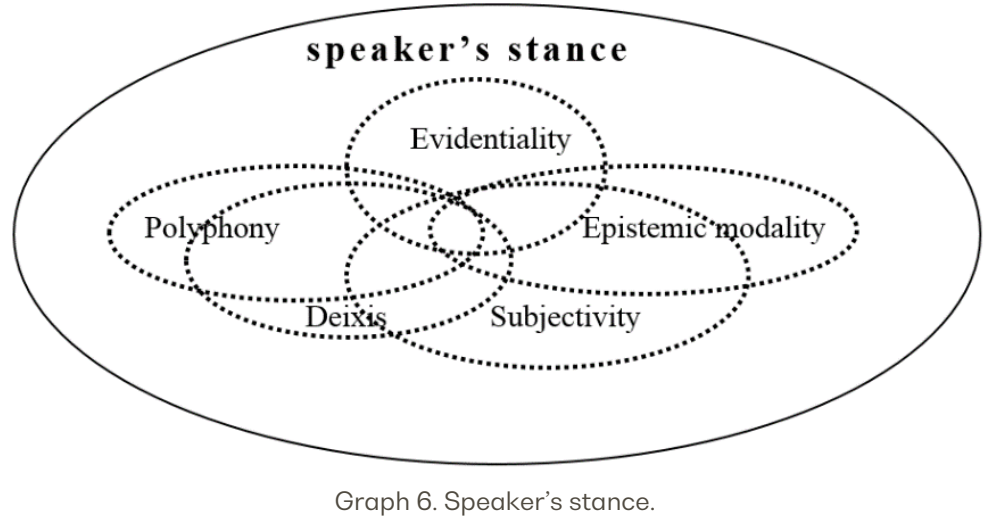

\subsection{THE IMPERFECT AS EXPRESSION OF EVIDENTIALITY}

In the following the use of an indicative verb form, to be more precise the imperfect, as expression of evidentiality will be studied. In fact, in its "non-typical" use, the imperfect can convey non-factuality and counter-factuality, but as well evidentiality (cf. BÖHM 2016). Nonfactual utterances are those in which the speaker makes no statement about the veracity of the utterance; in counter-factual utterances the narrator negates this veracity. In the following example the business deal is by no means concluded. On the contrary, closure of the deal is declared to be impossible because a condition is lacking.
(23) Si yo
pudiera,mocito, este trato
se cerraba
'If I could, fellow, this deal would be closed.'
REFL close.3.s.IPFV
(CORDE, ${ }^{2}$ García Lorca, Poesía Española, Antología por Gerardo Diego, 313)

The function of the English modal verb would is assumed in the Spanish sentence by the imperfect. In examples like (23) the conditional construction provides a context for the interpretation of the imperfect as irrealis. However, the use of the imperfect is different in the following sentence from language used in the press: 
(24) Peres reconocía ayer que el presidente sirio, Hafez El Assad, será el gran ausente de la cumbre, si bien ha sido informado por Mubarak de todos los detalles.

'Peres acknowledged (ipfv) yesterday that the Syrian president, Hafez El Assad, would be the "great absentee" at the summit, although he was informed by Mubarak about all the details.' (CREA, La Vanguardia, 02/02/1995, Política)

In this case, the use of the imperfect appears to contradict all prototypical characteristics. What is reported here is a singular, temporally localised and completed utterance by Peres. This would seem to call for the use of the simple perfect, as in the following example (25):

(25)Juppé reconoció ayer que los ingresos fiscales "están en una auténtica situación de siniestro", al no haberse cumplido las previsiones de crecimiento.

'Juppé acknowledged.prf yesterday that tax revenues are "in a really disastrous situation", since the growth forecasts were not fulfilled.' (CREA, La Vanguardia, 30/09/1995, Economía y Hacienda)

Why doesn't the example in (24) meet our expectations in terms of the "prototypical" use of the verb? This is a report about a unique and completed statement by Peres, for which - like the example (25) in the report about the statement by Juppé - a perfective verb form (reconocio) would be expected. The opposition of the perfective and imperfective verb form is not without function. Rather, with the use of the Spanish imperfecto a subjective nuance can be introduced into the text, which also includes the possibility of referring to a vague and unspecified source. The use of the imperfect in journalistic texts has to do with the reduction of the recourse obligation of the journalist, i.e. the extent to which he or she takes responsibility for the written content. The use of the imperfect arises here from the evidentiality as means of bringing forth the fact that the content of the utterance is taken from a source. While in the example (25) the acknowledgment is simply stated as a fact, the use of the imperfecto in journalistic texts reduces the recourse obligation of the journalist and therefore has to do with stance-taking.

By using the imperfect past tense, the speaker makes a very economical decision. The world knowledge of the speaker concerning the fact that something which is indefinite in its beginning and end therefore has a lesser degree of assertiveness or applies only under certain conditions, and enables the transmission to the expression of stance.

The imperfect occurs in a similar function in several Romance languages today (cf. LABEAU; LARRIVÉE, 2005). It enables the opening of another speaker deixis, without the need for naming the other deictic centre. Such uses are particularly striking in journalistic language. The imperfect forms in the examples (26) to (28) are used to present actions that are completed and determined as far as time is concerned. While here perfective verb forms could also be expected, the journalists use the imperfect, which allows them to refrain from taking responsibility for the contents and to indicate that they gained the information 
conveyed from observation, from another individual or from own reflection, without however stating an exact source. Often such uses have been declared as narrative imperfect, which denotes the character of the type of text, but does not contradict the statement of an evidential value:

(26)Spanish: Al día siguiente de aparecer en las páginas de este diario un artículo suyo sobre la situación de la Universidad, el director del Colegio Mayor Diego de Covarrubias, Diego Mateo del Peral, recibía un oficio del rector de la Universidad Complutense de Madrid en el cual le comunicaba que había propuesto su cese inmediato a la junta de gobierno de la referida universidad. (CREA, El País, Educación, 04/08/1997)

The day after the publication of his article on the situation of the university in this newspaper, the director of Colegio Mayor Diego de Covarrubias, Diego Mateo del Peral, receivedimpf a letter from the Rector of Complutense University in Madrid, in which he informed him that he had proposed his immediate termination as member of the board of directors of this university.

(27) French: On y disait que le directeur du corps de ballet ne lui avait vraiment pas laissé de passe-droit, [...] (source: http://www.voir.ca/cinema/fichefilm.aspx?ilDFilm=5045) 'One saidimp there, that the ballet director did not really give her preference.' [It was said there that the ballet director did not really let her have a leading role.]

(28) Portuguese: Há já algum tempo alguém evidenciava num artigo do Jornal Terras da Beira, as qualidades da equipa. (CDP, ${ }^{3} 18$ Set 97, A voz que vai morrer em directo) 'Already some time ago someone highlightedimp the qualities of the team in an article in the newspaper Terras da Beira.'

Particularly striking is the systematic use of the imperfect past tense in stock market reports, where, the imperfect is not only the tense that represents the ongoing changes in the value of the shares. It is used even though a specific time is mentioned and expressions like mardi après-midi ('Tuesday afternoon') or ayer ('yesterday') are usually triggers for perfective verb forms. Although concrete numbers and operations are presented, the author does not want to vouch for these and thus refers to these without mentioning the foreign source:

(29)L'action d'lsacsoft perdait 1,5 cent à 35,50 cents mardi après-midi à la Bourse. (http://www.lapresseaffaires.com/article/20070327/LAINFORMER/70327146/5891/LAINFORMERO1)

'On Tuesday afternoon the share of Isacsoft lost $1.5 \%$ on the stock market to close at 35.50 cents.'

(30)Repsol, que ayer pagaba dividendo movió 23.984 millones de pesetas, y Fecsa, que lo paga hoy 6.310 millones de pesetas. (El Mundo, 09/01/1996, Negocios)

'Repsol, which paid out dividends yesterday, moved 2,984 million pesetas, and Fesca, which will pay out today, 6,310 million pesetas. 
Imperfect forms of the indicative, which are traditionally not considered to be evidentialising, may well therefore express stance-taking and evidentiality in a complex way. Besides the deixis of the present text producer, they can characterise an additional deixis, that of the source of information. This can become clear if we try to translate such a sentence into German. Since German does not have any aspectually marked verb forms, other forms of marking evidentiality must be used, such as polyfunctional modal verbs, or overt modalisations with the subjunctive or modal particles, such as in the translations of the sentence (31):

(31) Diego Mateo del Peral, recibía un oficio del rector de la Universidad 'Diego Mateo del Peral receivedimp a letter of the rector of the University.'

(31) a. Diego Mateo del Peral sol/einen Brief des Rektors der Universität erhalten haben. 'Diego Mateo del Peral should (modal verb) have received a letter of the rector of the University.'

(31) b. Diego Mateo del Peral habe einen Brief des Rektors der Universität erhalten. 'Diego Mateo del Peral might have (conjunctive) received a letter of the rector of the University.'

(31) c. Diego Mateo del Peral erhielt woh/einen Brief des Rektors der Universität. 'Diego Mateo del Peral probably received a letter of the rector of the University.'

However, since overt evidential marking is more explicit and less subtle, they are also often omitted in translations:

(31)d. Diego Mateo del Peral erhielt einen Brief des Rektors der Universität. 'Diego Mateo del Peral, received a letter of the rector of the University.'

Of course, there are other linguistic means to reduce the responsibility of the text producer for the content of the utterance and to mark it evidentially, as for example Nølke (1994) has shown for il semble and il parait que and Rodríguez-Somolinos (2017) for il m'est avis que, apparemmentand il parait que in French. As the above-mentioned examples show, the means of expression of evidentiality and epistemic modality are language-specific and not easily transferrable from language to language.

\subsection{THE EMERGENCE OF NEW EVIDENTIAL MARKERS}

It is easy to understand that marking the source of knowledge is a cognitive and a communicative need whose disregard can have serious consequences. As we have seen, there is no tendency towards a stronger demarcation and specialization of the available linguistic means in special kinds of evidentiality; for example, to mark the origin of the communicated knowledge from visual observation or from hearsay. But what about the 
emergence of new evidential markers? The simplest solution would be the formation of adverbial constructions based on the expression of vision or visual appearance.

Indeed, a strikingly large number of constructions with the etymological meaning of seeing or visual appearance have become multiple-element adverbials in European languages: Spanish al parecer(cf. KOTWICA 2013; MARTÍN ZORRAQUINO 2013; CORNILLIE; GRAS 2020), Portuguese ao parecer and ao que parece, French avoir l'air de, Italian in apparenza and Russian по-видимому (cf. BÖHM; HAßLER; HENNEMANN 2017). These adverbial constructions do not have the same meaning and have a broad range of functions. Their morphological structures vary, but typical for all of them is the interplay of prepositional and (in some cases deverbal) nominal components:

$\begin{array}{ll}\text { Span. al parecer } & \text { preposition + article infinitive } \\ \text { Port. ao parecer } & \text { preposition + article infinitive } \\ \text { Port. ao que parece } & \text { preposition + article conjunction verb form } \\ \text { French: avoir l'air de } & \text { verb article substantive preposition } \\ \text { Ital. in apparenza } & \text { preposition (deverbal) substantive } \\ \text { Russ. по-видимому } & \text { preposition substantivised deverbal adjective }\end{array}$

Al parecer can be found in a non-specific evidential function in texts originating from the first half of the 17th century. By non-specific evidential function the reference to a source of knowledge is meant, whereby it remains open whether the statement is based on one's own view or conclusion, or whether it comes from a third party. In the following example, the contagious character of an illness is communicated evidentially. A degree of uncertainty as to whether the illness is in fact contagious also resonates in the sentence:

(32) [...] muchos enfermos y de enfermedad al parecer contagiosa, que comenzaba á cundir entre gente de importancia. (CORDE, Anónimo, Noticias de la Corte, 1659-1664)

'[...] many sick [people] and of apparently contagious diseases, which began to spread among important people.'

Some of the examples found in the Portuguese corpus refer to the outward appearance, and it is doubted whether this is a true reflection of the facts:

(33)A dona da casa, por certo traquejada nessas bolandinas do marido, estava sossegada, ao menos ao parecer. (CDP; Simões Lopes Neto, Contos Gauchescos, 1912).

'The mistress of the house, surely experienced in these mad outbursts of her husband, was quiet, at least apparently.'

It is probably attributable to the lexicalisation of ao parecer with the meaning 'view, opinion, expertise' that the unspecific evidential meaning is largely expressed in Portuguese with another construction: ao que parece. Ao que parece is used mostly parenthetically. It is inserted into the sentence (34), placed at its beginning (35) or its end (36): 
(34)A lei, ao que parece, caiu em desuso. (CDP; Lima Barreto, Os Bruzundangas) 'The law, it seems, has fallen into disuse.'

(35) Ao que parece, este doutor Carvalho nunca empregou [...] (CDP, Lima Barreto, Vida Urbana) 'Apparently, this doctor Carvalho never employed [...]'

(36)Tanto que com ela ele ousou, ao que parece. (CDP, BernardoCarvalho, Os Bêbados e Os Sonâmbulos, 1996)

'So much so that with her he dared it, it seems.'

In all, ao que parece proves in Portuguese to be an element that is specialised in expressing unspecific evidentiality and that can be used in various syntactic positions, but that clearly prefers parenthetical usage.

The results for Italian all'apparenza and in apparenza are very similar. All'apparenza can, however, also denote the visual origin of the speaker's knowledge:

(37) Un tipo tosto, all'apparenza, atletico e belloccio.

(http://www.cronacaqui.it/news/apri/17202)

'A cool guy, apparently, athletic and handsome.'

Unspecific evidentiality can also be expressed by using the combination of a preposition and apparenza. In example (38), both a conclusion and a communication by a third party are possible:

(38) In apparenza, il discorso dell'amministrazione americana è persino convincente. (http://italy.peacelink.org/pace/articles/art_12317.html)

'Apparently, the speech of the American administration is even convincing.'

In French, the construction $\dot{a}$ l'apparence took on the meaning of a deceptive appearance very early, and it is not used adverbially but always refers to an appearance of a certain fact or person. The following quote is designed to illustrate this meaning of an appearance that can possibly be accurate:

(39)[...] c'est celui auquel on n'a presque jamais pensé, et que l'on a toujours été prêt à sacrifier à l'appât d'un gain sordide et à l'apparence du moindre profit à faire sur l'étranger. Je dis à l'apparence; je ne prétends pas insinuer par-là que ce profit soit toujours illusoire [...] (Frantext, M472 - Destutt de Tracy, Commentaire sur l'Esprit des Lois de Montesquieu, 1807, p. 341, Livres XX, XX)

'[...] that's the one from whom we hardly ever thought it, and that you were always ready for him to abjure the lure of sordid gain and the appearance of lesser profit to be made in the foreign countries. I say the appearance; I do not pretend to insinuate that this profit is always illusory [...]'

The meaning that was specified in the other Romance languages by a construction that comes from the combination of a preposition and a nominal element is assumed in French 
by the adverb apparemment and the verbal expression avoir l'air de. Apparemment can be found with an unspecific evidential and modal meaning very early on:

(40)[...] et le met si près du principe de toute grandeur, qu'encore qu'apparemment il n'y ait rien de plus éminent que la royauté [...] (Frantext, Q738 - Jean-Louis Guez de Balzac, Le Prince, 1631, p. 80)

'[...] and it is put so close to the principle of all greatness so that apparently there is nothing more prominent than royalty [...]'

From the data discussed in this study with regard to the functions and syntactic usages of the construction comprising a preposition and a nominal element in different languages we can derive some insights for the understanding of evidentiality.

Firstly, it can be concluded that the lexemes with the two meanings 'visible' and 'apparent' in combination with a preposition, the spatial meaning of which is a direction, show the tendency of developing an evidential meaning. This tendency is total in Spanish, but less defined in Italian. In Portuguese, the special lexicalisation of parecer gives rise to the substitute construction ao que parece, whereas in French the largely monosemantic usage of à l'apparence rules out evidential usages. In Italian, all'apparenza / in apparenza occurs evidentially, but also with the meaning 'apparently in contradiction with the real situation'.

Secondly, the evidential value of these constructions proves to be indeterminate, i.e. the decision whether an occurrence represents inferential and hearsay evidentiality depends on the context and is not determined by the evidential markers themselves. It therefore appears to be justified to speak of an unspecified evidential function.

Thirdly, the evidential markers can be used parenthetically and non-parenthetically, with a broad or with a narrow scope. They can largely be placed as desired, whereby a placement at the end of the sentence occurs very rarely in Spanish. Where the usage is at the end of a sentence or with a narrow scope, it is always in spoken language or with the aim of depicting spoken language in a written text. The prototypical uses of the evidential markers are hence the parenthetical placement at the beginning and in the middle of a sentence, and the broad scope. The usage with narrow scope is considered to be conspicuous and therefore simultaneously serves to mark a focus.

Another starting point for the emergence of new evidential markers are constructions that consist of a verb of saying and a complementizer. Studies on the Spanish dizque assume that this form falls into two categories, between which there is a continuum: on the one hand it is a particle, on the other a verbal modifier (DE LA MORA; MALDONADO 2015; ALCÁZAR, 2018, p. 726). As a particle dizque has a relatively unlimited distribution (KALTENBÖCK; HEINE; KUTEVA, 2011, p. 852-854) and various semantic and pragmatic functions. Thus, dizque can express quotative, reportive, indirect evidential, epistemic modality and mirativity. As a verbal modifier, dizque produces a new syntactic unit with the 
verb, which has primarily evident meaning and at most weak epistemic associations. In this use, dizque has scope over the entire sentence and, at least in Colombian and Ecuadorian Spanish, has characteristics that are appropriate to a grammaticalized evidential. As a result of grammaticalization processes, dizque can emerge from the merging of the 3rd person singular (41), the 3rd person plural (42) or the pronominalized impersonal form (43) with the complementiser que (cf. ALCÁZAR 2018, 729):

(41) Dice que llegaron tarde.

(42) Dicen que llegaron tarde.

(44) Dizque llegaron tarde.

(43) Se dice que llegaron tarde.

As Travis (2006) has already noted, dizque can occur in Colombian Spanish with a purely evidential function in quotative (45) or reportive (46) meaning (see ALCÁZAR 2018: 729):

(45)A: Y yo dizque

M:@@@

$A:[X X X],<V O X$ mi amor. ¿A qué horas fue que llegamos VOX?>

$Y<@ n o$, dizque@>,<VOX No, hace como dos o tres horas VOX>

Y hacia como media hora acabábamos de llegar.

(46)porque dizque iba a enterrar a una persona.

In addition, dizque can also express doubts about the content of the statement in epistemic-modal function. Especially in uses with scope on adjectives the epistemic reading is salient (47) (cf. ALCÁZAR, 2018, 730):

(47) - Pues, ¿qué oíste?

Una cosa que dijeron los del gobierno ese dizque provisional.

Tendencies similar to those in Colombian and Ecuadorian Spanish can also be found in Brazilian Portuguese. It should be noted that the emergence of evidentials from forms of the verb for "to say" has also been observed in other Romance languages, especially in languages of peripheral regions of the Romance countries, e.g., by Cruschina and Remberger (2008) for Galician, Romanian, Sardinian and Sicilian, by Haßler (2002) for Canadian French and by FRIEDMAN (2000) for Romanian. López Izquierdo (2006) described the emergence of dizque as an evidential strategy (stratégie médiative) in medieval Spanish.

Linguistic means that could become markers of evidentiality, in this case reportative and quotative evidentiality, were thus present in the Romance languages. The fact that a marker such as $\operatorname{diz}(\varnothing)$ que established itself more strongly in certain varieties of Spanish and in Brazilian Portuguese than in other varieties may be related to the presence of 
obligatory evidentials in the indigenous contact languages (HENGEVELD; HATTNHER 2015). Mandatory means of evidentiality create a compulsion to mark the origin of the speaker's knowledge, which may also be reflected in the use of a language without obligatory evidentiality.

As early as 2001, Vânia Cristina Casseb Galvão set herself the goal in her dissertation of proving that the construction (ele) diz que, starting from a matrix sentence in a grammaticalization process, has become an evidential marker in certain uses. In certain contexts, the construction diz que introduces an embedded sentence, but it does not fulfil a predicative function and does not demand an agent of speech. The following example shows that in the real world there is no referent to which the role of the origin of the utterance can be ascribed:

(48)L1 [...] e assim:: morreu um colosso de gente aqui em São Paulo nessa ocasião que foi ...() L2 diz que em Jundiaí também enterravam ...agora (da um) [...] em ( ) Campinas foi menos (NURC/SP,D2, INQ.396)

In this example, the diz que construction not only introduces an unconfirmed piece of information, but it also characterizes the speaker's strategy of making the interlocutor understand that he or she is not the source of the information himself or herself and that he or she does not want to identify it. Such uses of the construction diz que are particularly common in spoken language and were first demonstrated in the Xingu (GALVÃO 2001: 21), a group of indigenous people living on the upper reaches of the Rio Xingu in Mato Grosso, Brazil.

Although diz que in the example (48) is clearly used in the evidential sense, there are also indications of the speaker's attitude to the truth value of the proposition. As we have already seen in other evidential markers, identifications of the origin of the speaker's knowledge are often associated with modal values, especially in languages without grammatical evidentials.

The development of diz que into an evidential and epistemic marker can be easily understood by looking at the change in its function compared to the embedded predication. In the following sentence, tia Ursula diz is a matrix sentence that introduces the proposition.

(49) Tia Ursula diz que a água daqui faz bem ao cabelo (...) (PD -LD) (GALVÃO, 2001, 21)

In this use, the verb dizer denotes a relationship between a human being and the act of speaking which it takes as its second argument. Dizer thus appears here in a predication in which the embedded predication que a água daqui faz bem ao cabelo is an argument of the verb. This diz que can be called a predicative construction, whereas the evidential marker diz que is non-predicative (cf. GALVÃO, 2001: 131). 
The diz que, reanalysed as a non-predicative evidential marker, no longer binds a subject and is no longer inflected by tense, mode or person. In the following examples, diz que is used with a non-predicative function, a carrier of the action of saying is not present and is not implied. Diz que in (50) marks indirect evidentiality, in (51) inference and in (52) hearsay:

(50) Diz que era um rei, tinha uma filha por casar...(CNT-LR)

(51) Geni: Pois e, no Cassino da Urca, olha que chique. Parece ate que ela e uma jovem muito simpatica, culta, prendada...E rica, e claro. Diz que a família dela tem muito dinheiro. $(\mathrm{OM}-\mathrm{LD})$

(52) Bastiao: Diz que pedacim do chifre cura quebrante. (REBLD) (examples from GALVÃO, 2001)

As a marker of the narrated world as in (50), diz que appears particularly in Portuguese as a contact language among speakers of the indigenous language Baniwa (GALVÃO, 2001: 137), which is spoken in the border region of Brazil, Colombia and Venezuela. The construction is productive with this meaning especially in the introduction of fables, legends and folklore texts.

As we have already seen with other markers, diz que can also be used to confirm a generally known truth, reproduce hearsay and express the speaker's assumptions. This polyfunctionality does not contradict its function as a marker of generalised evidentiality. For Brazilian Portuguese, it is not possible to speak of a grammaticalised system of evidentiality in which different evidential values are distributed among specific linguistic forms. The influence of contact languages with grammaticalised evidentials can be seen more in the intensity of the use of evidential markers than in demarcations according to different sources of knowledge. In Brazilian Portuguese, the expression of evidential values is primarily lexical, in addition to the verb forms of the conditional, the imperfect (HAßLER, 2016, 332-340) and the future tense (OLIVEIRA, 2015), which also occur in other Romance verb forms. Lexical markings of the origin of knowledge can also be used for several sources and can also have modal meanings. In contrast to predicative use, the marker diz que is modified in that it regularly occurs without a subject and no concrete reference to a cited speaker instance is given. The fact that the construction diz que can still be used in predicates, the non-existent obligatory nature of its use, and the mixing of several evidential meanings suggest that in this case it is not the result of a grammaticalisation process, but rather of pragmaticalisation. 


\section{CONCLUSION: THE EXPLANATORY POTENTIAL OF THE CATEGORY OF EVIDENTIALITY}

In the first grammatical descriptions of languages with grammatical evidentials, the descriptions were dominated by subordination to categories of the Greco-Latin grammatical tradition. This procedure of transferring descriptive categories of well described languages to languages that had not yet been described is also called exogrammatisation.

However, as early as 1560 Santo Tomás added a chapter to his grammar of Quechua on "some particular ways of speaking" (SANTO TOMÁS, 1560, 36) which are not found in the Latin or Spanish language, followed by several chapters on the peculiarities of Quechua. In the following passage, Santo Tomás clearly describes reportative evidentiality:

\footnotetext{
Ha de notar mas otra cosa en esta lengua, que no solamente en ella ay la deriuacion, composición de los verbos vnos de otros como esta dicho: mas aun causase alguna manera de diversidad en su significación en solo añadir o quitar vna letra, y assi aquella $s$ de suyo nada significa, mas de ser letra: todas las vezes que se añade, tenga otra distincta manera de significar dela que tenía antes que se añadiesse. Exemplo del verbo. (micungul) significa, comes, añadida aquella $s$, al cabo, diciendo (micunguis) significa, dize, o dizen que comes. Item (micurcangui) significa comiste, dizendo (micurcanguis) significa dizen, o dize que comiste. Exemplo del nombre. (cam) significa tu (cans) significa dizen que tu (ñoca) significa yo (ñocas) significa dizen o dize que yo, y assi de todos los demas. Añadese muchas vezes ala $s$, esta letra e, como en los exemplos dichos (camse) dizen que tu, (ñocase) dizen que yo. Y esto es mas común enlos nombres que enlos verbos. Por manera que la consignificacion de aquella letra $s$, añadida a nombre, o verbo: es hacer que se entienda enel lo que dezimos en romance dicen que haces, o hagas o has hecho el acto del verbo o que se añade, como parece enlos exemplos dichos: y assi en todos los demás, y es una manera muy elegante y vsada de hablar entre los Indios. (SANTO TOMÁS, 1560, 41)
}

With this description Santo Tomás took several steps towards the conceptualization of evidentiality: (1) He realized that this phenomenon of the sound $s$ did not fit into the grammar anchored in Latin and other European languages. (2) He performed an act of abstraction, recognizing a common use of the $s$, even with verbs and nouns. (3) He dared to attribute a meaning to the $s$ which was considered as a word without a meaning and called this process consignificación. (4) He identified variants of this marker. (5) He classified the use of the marker $s /$ se stylistically as a very elegant and useful way of speaking.

Some discursive particles that mark the evidentiality were described also by González Holguin (1607) as particles that change the meaning of the sentence a little, such as -cha which means dizen, no se, quiça, o creo que ('they say, I do not know, maybe, or I believe that') and particles that change the sense entirely, such as -mi and-si, with the meaning dizen, dizen affirmando o preguntando (the say affirming or asking) (cf. CALVO LÓPEZ, 1994 and TORRES SÁNCHEZ, 2013, 31).

For the Aymara language there are missionary descriptions in which some evidentials are mentioned. In the Art of the Aymara language (Arte de la lengua aymara 1603) by the Jesuit Ludovico Bertonio we find, for example, the observation that the Indians use the 
particle - cha to tell of something they have not seen themselves, but have learned it from someone. (BERTONIO, 1603: Part III: 275, CALVO LÓPEZ, 1997: 334, TORRES, 2013: 35). In the case of evidentiality, there were then, in addition to exogrammatisation procedures, also specific approaches to Amerindian languages.

The first to use the term evidentia/in a theoretical context was Roman Jakobson in his article Shifters, verbal categories, and the Russian verb ([1957] 1971), where he used this term to designate a verbal category involving the interaction between three events: the narrated event, the speech event, and the narrated speech event. Jakobson established four sources of information: rumour (quotative, hearsay evidentiality), dream (revelative evidentiality), conjecture (presumptive evidentiality), and past experience (memory evidentiality), referring to the Amerindian (Kwakiutl, Hopi) and Slavic (Bulgarian, Macedonian) languages. He quotes Boas's work on Kwakiutl and also mentions works by other authors where the description of evidentials could be found.

\footnotetext{
Certain languages, as for instance Bulgarian (s. Andrejčin), Kwakiutl (s. Boas), and Hopi (s. Whorf), use particular morphological devices to denote events known to the speaker only from the testimony of others. Thus, in Tunica all statements made from hearsay (and this covers the majority of sentences in the texts aside from those in direct discourse) are indicated by the presence of /-áni/, a quotative postfix used with a predicative word (Haas). (JAKOBSON, [1957] 1971, 130-131)
}

Already in the first descriptions of evidential markers, the authors associated the function of marking the source of knowledge with other functions, for example, with the insecurity of the speaker or the desire not to take responsibility for the content.

On the one hand, the defenders of the strictly grammatical approach maintain that only those linguistic elements that are specialized in marking evidentiality can be considered as evidentials. Alexandra Aikhenvald defines evidentials as constructions whose standardized semantic core is the 'source of information': "To be considered as an evidential, a morpheme has to have 'source of information' as its core meaning; that is, the unmarked, or default interpretation" (AIKHENVALD, 2004, 3).

On the other hand, evidentiality has been integrated into functional and pragmatic linguistics. This integration is not in contradiction with the use of this category in typological works on the existence of a grammatical core of evidentiality in some languages, which allows a comparison of the linguistic resources that perform this function in other languages (cf. GUENTCHÉVA, 2018).

The concept of evidentiality has an explanatory potential because it can be used to trace various linguistic phenomena back to the effect of the cognitive and communicative compulsion to mark the origin of the knowledge communicated. First of all, it is confirmed that marking the origin of speaker knowledge is a functional area that is both cognitively and communicatively relevant, but which is grammatically defined in only a few languages. This finding does not exclude the possibility that grammatical forms that have become 
redundant in certain environments and types of text have a clear tendency to be used for the expression of this function even in languages without specific evidentials. The developments taking place in this context can be seen as an action of the principle of economy in language against the background of a high complexity of functions.

From a historical point of view, it would be necessary to consider how forms and functions of evidentiality have changed. Parallel developments as well as differences between different Romance languages can be observed. Text type-specific procedures for marking evidential content are also subject to change. In this connection, it would also be necessary to consider whether the interaction of modality and evidential content in different types of texts shows differences, and whether the nature of these differences may be language-specific due to different traditions of discourse (cf. for example BORREGUERO ZULOAGA 2017; CORNILLIE; PIETRANDREA 2012, SENTì 2020).

By evaluating the material examined so far, this article should have presented two findings and at the same time shown that they provide a potential explanation for the concept of evidentiality in Romance languages. Evidential expressions, which go back to lexical designations of the speaker's source of knowledge, are subject to a process of pragmatic change associated with semantic changes, as a result of which they become unspecified evidential markers. Certain grammatical forms in Romance languages, such as the conditional or the imperfect, can be used as evidentialisations without further "support", whereby their prototypical meaning recedes.

The concept of 'evidentiality' is the only example of reverse exogrammatisation, in which a category derived from the description of Amerindian languages is used for the description of European languages.

\section{REFERENCES}

ALBELDA MARCO, Marta. Evidentiality in non-evidential languages: Are there evidentials in Spanish? Journal of Pragmatics, v. 85, 2015, p. 135-137. DOI: org/10.1016/i.pragma.2015.04.002

AIKHENVALD, Alexandra. Evidentiality. Oxford: University Press, 2004.

AIKHENVALD, Alexandra. Information source and evidentiality. Italian journal of linguistics, v. 19, n. 1, 2007, p. 209227.

ALCÁZAR, Asier. "Dizque and other emergent evidential forms in Romance languages". In: AIKHENVALD, Alexandra Y. The Oxford Handbook of evidentiality. Oxford: Oxford University Press, 2018, p. 725-740.

BARNES, Janet. Evidentials in the Tuyuca verb. International Journal of American Linguistics, Chicago, v. 50, p. 255$271,1984$.

BERTONIO, Ludovico. Arte y grammatica muy copiosa de la lengua aymara. Roma: Luis Zannetti, 1603.

BÖHM, Verónica. La imperfectividad en la prensa española y su relación con las categorías semánticas de modalidad y evidencialidad. Frankfurt a. M. et al.: Peter Lang, 2016. 
BÖHM, Verónica; HASSLER, Gerda; HENNEMANN, Anja. On the evidential use of English adverbials and their equivalents in Romance languages and Russian. A morpho-syntactic analysis. In: Marín Arese, Juana l.; Haßler, Gerda; Carretero, Marta (eds.), Evidentiality revisited. Cognitive grammar, functional and discourse-pragmatic perspectives. Amsterdam: John Benjamins Publishing Company, 2017, 87-104.

BONDARKO, Aleksandr Vladimirovič. Teorija grammatičeskogo značenija i aspektologičeskie issledovanija. Leningrad: Nauka, 1984.

BORREGUERO ZULOAGA, Margarita Natalia, Los relatos coloquiales: partículas discursivas y polifonía. Pragmalingüística, Editorial Universidad de Cádiz, v. 25, p. 62-88, 2017.

https://revistas.uca.es/index.php/pragma/article/view/3674

BOYE, Kasper. Epistemic meaning. A crosslinguistic and functional-cognitive study. Berlin; Boston: De Gruyter, 2012.

BOYE, Kasper. "Evidentiality. The notion and the term". In: Aikhenvald, Alexandra Y. The Oxford handbook of evidentiality. Oxford: Oxford University Press, 2018, p. 261-272.

CALVO LÓPEZ, Julio. "La gramática aimara de Bertonio 1603". In: ZIMMERMANN, Klaus. La descripción de las lenguas amerindias en la época colonial. Frankfurt: Iberoamericana, Madrid: Vervuert, 1997, p. 321-378.

CARRETERO, Marta; MARÍN-ARRESE, Juana I.; LAVID-LÓPEZ, Julia. Adverbs as evidentials: an English-Spanish contrastive analysis of twelve adverbs in spoken and newspaper discourse. Kalbotyra, Vilnius, v. 70, p. 32-59, 2017. https://doi.org/10.15388/Klbt.2017.11185.

CORNILLIE, Bert. Evidentiality and epistemic modality in Spanish (semi)auxiliaries. A cognitive-functional approach Berlin: Mouton de Gruyter, 2007 (Application of cognitive linguistics series 5).

CORNILLIE, Bert. On speaker commitment and speaker involvement. Evidence from evidentials in Spanish talk-ininteraction. Journal of Pragmatics, Elsevier, v. 128, p. 161-170, 2018. Doi: org/10.1016/i.pragma.2017.11.014.

CORNILLIE, Bert; GRAS, Pedro. Evidentiality and Socioepistemic Status of Participants. A Case Study of Spanish por lo visto 'seemingly' and al parecer 'apparently'. Catalan Journal of Linguistics Special Issue, Universitat Autònoma de Barcelona, p. 183-204, 2020. doi.org/10.5565/rev/catjl.321.

CORNILLIE, Bert; PIETRANDREA, Paola. Modality at work. Cognitive, interactional and textual functions of modal markers. Journal of Pragmatics, v. 44, n. 15, p. 2109-2226, 2012

CRUSCHINA, Silvio; REMBERGER, Eva-Maria. Hearsay and reported speech: evidentiality in Romance. In: SELECTED PROCEEDINGS OF THE XXXIV INCONTRO DI GRAMMATICA GENERATIVA. Special issue edited by P. Benincà, F. Damonte \& N. Penello. = Rivista di grammatica generativa, Venice, v. 33, p. 95-116, 2008

DANKEL, Philipp; RODRÍGUEZ, Mario Soto. Convergencias en el área andina: la testimonialidad y la marcación de la evidencialidad en el español andino y en el quechua. Neve Romania, Freie Universität Berlin, v. 41, p. 89-120, 2012. URL: https://edoc.unibas.ch/64250/.

DE HAAN, Ferdinand. The relation between modality and evidentiality. In: MÜLLER, Reimar; REIS, Marga. Modalität und Modalverben im Deutschen. Hamburg: Helmut Buske Verlag, 2001, p. 201-206.

DE HAAN, Ferdinand. Encoding Speaker Perspective: Evidentials. In: FRAJZYNGIER, Zygmunt: HODGES, Adam; ROOD, David S., Linguistic Diversity and Language Theories. Amsterdam: John Benjamins, 2005, 379-397.

DE LA MORA, Juliana; Maldonado, Ricardo. Dizque: Epistemics blurring evidentials in Mexican Spanish. Journal of Pragmatics, v. 85, p. 168-180, 2015. Doi: org/10.1016/i.pragma.2015.03.019.

DENDALE, Patrick; TASMOWSKI, Liliane (eds.). Les sources du savoir et leurs marques linguistiques. Paris: Larousse 1994 (= Langue Française 102)

ESTRADA, Andrea, Panorama de los estudios de la evidencialidad en el español. Teoría y práctica. Ciudad Autonoma de Buenos Aires: Teseo, 2013.

FRIEDMAN, Victor. Confirmative/nonconfirmative in Balkan Slavic, Balkan Romance, and Albanian with additional observations on Turkish, Romani, Georgian, and Lak. In: JOHANSON, Lars; UTAS, Bo (eds.), Evidentials. Turkic, Iranian and neighbouring languages. Berlin: De Gruyter, 2000, p. 329-366. 
GALVÃO, Vânia Cristina Casseb. Evidencialidade e gramaticalização no português do Brasil: os usos da expressão diz que. 2001. Doctoral thesis. Universidade Estadual Paulista Araraquara, 2001.

GONZÁLEZ RUIZ, Ramón; IZQUIERDO ALEGRÍA, Dámaso; LOUREDA LAMAS, Óscar. La evidencialidad en español: teoría y descripción. Madrid: Iberoamericana; Frankfurt am Main: Vervuert, 2016.

GUENTCHÉVA, Zlatka (ed.). Epistemic modalities and evidentiality in cross-linguistic perspective. Berlin; Boston: Walter de Gruyter.

HAßLER, Gerda. Evidentiality and reported speech in Romance languages. In: Güldemann, Tom; Roncador, Manfred von. Reported discourse. A meeting ground for different linguistic domains. Amsterdam: John Benjamins, 2002, 143172.

HAßLER, Gerda. El uso evidencial de adverbios modales. In: CUARTERO, Juan; WOTJAK, Gerd. Algunos problemas especificos de la descripción sintáctico-semántica. Berlin: Frank \& Timme, 2004, 229-244.

HASSLER, Gerda. Temporalität, Aspektualität und Modalität in romanischen Sprachen. Berlin; Boston: Walter de Gruyter, 2016

HENGEVELD, Kees; HATTNHER, Marize Mattos Dall'Aglio. Four types of evidentiality in the native languages of Brazil. Linguistics, De Gruyter, v. 53, n. 3, p. 479-524, 2015. DOl: 10.1515/ling-2015-0010.

HENNEMANN, Anja. A Context-sensitive and Functional Approach to Evidentiality in Spanish or Why Evidentiality needs a Superordinate Category. Frankfurt am Main: Peter Lang, 2013. (Potsdam Linguistic Investigations 10).

IZQUIERDO ALEGRÍA, Dámaso; GONZÁLEZ RUIZ, Ramón; LOUREDA LAMAS, Óscar. Un acercamiento a los fundamentos de la evidencialidad y a su recepción y tratamiento en la lingüística hispánica. In: IZQUIERDO ALEGRÍA Dámaso; GONZALEZ RUIZ, Ramón; Loureda Lamas, Oscar. La evidencialidad en español: teoría y descripción. Vervuert, p. 9-45 2016. DOI: org/10.31819/9783954878710-001

JAKOBSON, Roman. Selected writings. La Haye: Mouton, [1957] 1971

JAKOBSON, Roman. On linguistic aspects of translation. In: BROWER, Reuben A. On translation. Cambridge, Mass: Harvard University Press, 1959, p. 232-239

KALTENBÖCK, Gunther; HEINE, Bernd; KUTEVA, Tania. On thetical grammar. Studies in Language, Benjamins, v. 35 , n. 4, p. 852-897, 2011. https://doi.org/10.1075/sl.35.4.03kal.

KOTWICA, Dorota, Los valores del significado de la partícula evidencial "al parecer". La atenuación y el efecto de disociación. In: Cabedo Nebot, Adrián; Aguilar Ruiz, Manuel José; López-Navarro Vidal, Elena. Estudios de lingüística: investigaciones, propuestas y aplicaciones, Valencia: Universitat de València, 2013, 403-411.

LABEAU, Émmanuelle; LARRIVÉE, Pierre. Nouveaux développements de l'imparfait. Amsterdam; New York: Rodopi, 2005.

LOPEZ IZQUIERDO, Marta. L'émergence de dizque comme stratégie médiative en espagnol médiéval. Cahiers d'études hispaniques médiévales, Paris E.N.S. Éditions, v. 29, p. 483-493, 2006. http://hal.archives-ouvertes.fr/hal00179539

MARTÍN ZORRAQUINO, Maria Antonia. La polifonía en algunos signos adverbiales disjuntos que matizan la aserción en español actual (desde luego y sin duda; por lo visto y al parecer). In: GÉVAUDAN, Paul; ATAYAN, Vahram; DETGES, Ulrich. Modalität und Polyphonie,. Tübingen, Stauffenburg-Verlag, 2013, 103-130.

NØLKE, Henning. La dilution linguistique des responsabilités. Essai de description polyphonique des marqueurs évidentiels il semble que et il parait que. Langue française, v. 102, 84-94, 1994. DOI: https://doi.org/10.3406/lfr.1994.5716.

OLIVEIRA, Teresa. Between evidentiality and epistemic modality: The case of the future and the conditional in European Portuguese. Belgian Journal of Linguistics, Benjamins, v. 29, n. 1, p. 101-122, 2015. DOI: 10.1075/bjl.29.05oli.

PIETRANDREA, Paola. The grammatical nature of some epistemic-evidential adverbs in spoken Italian. Italian Journal of Linguistics / Rivista di linguistica, Pacini Editore, v. 19, n¹, p. 39-64, 2007. https://hal.archivesouvertes.fr/hal-00665200. 
RODRÍGUEZ-SOMOLINOS, Amalia. From visual perception to inference in the French evidential markers il m'est avis que, apparemment, and il parait que. Journal of Historical Linguistics, vol 7, n. 1, p. 111-133, 2017. doi: org/10.1075/ihl.7.1-2.05rod

SANTO TOMÁS, Diego. Grammatica, o Arte de la lengua general de los Indios de los reynos del Peru. Valladolid: Francisco Fernandez de Cordoua, impressor de la M.R., 1560.

SENTÍ, Andreu. The expression of evidentiality in spoken and written texts: empirical approaches to Romance languages. Anvari de Filologia. Estudis de Lingüística, Revistes Científiques de la Universitat de Barcelona, v. 10, p. 29-38, 2020. DOI: 10.1344/AFEL2020.10.2.

SQUARTINI, Mario. The internal structure of evidentiality in Romance. Studies in language, Benjamins, v. 25, p. $297-$ 334, 2001. DOI: org/10.1075/sl.25.2.05squ.

SQUARTINI, Mario. Lexical vs. grammatical evidentiality in French and Italian. Linguistics, De Gruyter, v. 46, n5, $917-$ 947, 2008. DOI: 10.151515/LING.2008.030.

SQUARTINI, Mario. Extragrammatical expression of information source. In: AIKHENVALD, Alexandra Y. The Oxford Handbook of evidentiality. Oxford: Oxford University Press, 2018, p. 273-285.

TORRES SÁNCHEZ, Nadiezhda. La evidencialidad en las lenguas indigenas americanas: un enfoque areotipológico. México: Instituto Nacional de Antropología e Historia, 2013. (Colección Lingüística. Serie Logos).

WEBER, David J. A grammar of Huallaga (Huánuco) Quechua. Berkeley: University of California Press, 1989. (University of California Publications in Linguistics 112).

WILLETT, Thomas. A cross-linguistic survey of the grammaticalization of evidentiality. Studies in Language, Benjamins, v. 12, n. 1, p. 51-97, 1988. https://doi.org/10.1075/sl.12.1.04wil. 